\title{
Documentation of Late Caddo Period Ceramic Vessels from Sites in the Lake Fork Creek Basin in Wood County, Texas
}

Timothy K. Perttula

Heritage Research Center, Stephen F. Austin State University

Bob D. Skiles

Follow this and additional works at: https://scholarworks.sfasu.edu/ita

Part of the American Material Culture Commons, Archaeological Anthropology Commons, Environmental Studies Commons, Other American Studies Commons, Other Arts and Humanities Commons, Other History of Art, Architecture, and Archaeology Commons, and the United States History Commons

Tell us how this article helped you.

This Article is brought to you for free and open access by the Center for Regional Heritage Research at SFA ScholarWorks. It has been accepted for inclusion in Index of Texas Archaeology: Open Access Gray Literature from the Lone Star State by an authorized editor of SFA ScholarWorks. For more information, please contact cdsscholarworks@sfasu.edu. 
Documentation of Late Caddo Period Ceramic Vessels from Sites in the Lake Fork Creek Basin in Wood County, Texas

\section{Creative Commons License}

(c) (1) (8)

This work is licensed under a Creative Commons Attribution-NonCommercial 4.0 International License 


\title{
Documentation of Late Caddo Period Ceramic Vessels from Sites in the Lake Fork Creek Basin in Wood County, Texas
}

\author{
Timothy K. Perttula and Bob D. Skiles
}

\section{INTRODUCTION}

In this article we document 18 ceramic vessels from three ancestral Caddo sites with cemeteries in the Lake Fork Creek basin in Wood County, Texas. Each site has a Late Caddo period Titus phase (ca. A.D. 1430-1680) component.

\section{BURKS SITE (41WD52) VESSEL}

The Burks site is a Titus phase hamlet in the Little Dry Creek drainage basin (see Perttula et al. 1993:Figure 4) in the East Texas Pineywoods. In addition to a number of midden deposits at the site that may represent household clusters, there is an associated cemetery at the southern end of the site (Perttula 2005:Figure 10). A single ancestral Caddo burial feature was excavated in 1978, and the interment was associated with a single smoothed pebble and eight ceramic vessels lying between 49-56 cm bs (Perttula 2005:Figure 11). One of the eight vessels in this burial is documented in this article.

SITE NAME OR SITE NUMBER: Burks (41WD52)

VESSEL NO.: Burial 1, Vessel C

NON-PLASTICS AND PASTE: grog and a clay paste

VESSEL FORM: Jar

RIM AND LIP FORM: Everted rim and a rounded lip

CORE COLOR: $\mathrm{G}$ (fired in a reducing environment and cooled in the open air)

INTERIOR SURFACE COLOR: very dark grayish-brown

EXTERIOR SURFACE COLOR: dark yellowish-brown; fire clouds on the base; organic residue on the rim and body

WALL THICKNESS (RIM, BODY, AND BASE IN MM): rim, 7.6 mm

INTERIOR SURFACE TREATMENT: smoothed

EXTERIOR SURFACE TREATMENT: smoothed on the vessel body

HEIGHT (IN CM): 18.5

ORIFICE DIAMETER (IN CM): 13.1 
DIAMETER AT BOTTOM OF RIM OR NECK (IN CM): 11.6

BASE DIAMETER (IN CM) AND SHAPE OF BASE: 8.0; circular and flat

ESTIMATED VOLUME (IN LITERS): 2.2

DECORATION (INCLUDING MOTIF AND ELEMENTS WHEN APPARENT): The rim has roughened and partially smoothed neck bands. There are also four equally-spaced appliqued nodes on the rim, as well as four other nodes just below the rim-body juncture and directly under the rim nodes. Below the body appliqued nodes are four vertical appliqued ridges that divide the vessel body into four plain panels.

PIGMENT USE AND LOCATION ON VESSEL: none

TYPE AND VARIETY [IF KNOWN]: La Rue Neck Banded

\section{HOLLY LAKE RANCH (41WD57) VESSEL}

The Holly Lake Ranch site is on Honey Creek in the Big Sandy Creek basin (Perttula et al. 1986:58 and Figure 9). A single vessel is documented from a burial at the site.

SITE NAME OR SITE NUMBER: Holly Lake Ranch (41WD57)

VESSEL NO.: Burial 1, Vessel 1

NON-PLASTICS AND PASTE: grog and bone

VESSEL FORM: Carinated bowl

RIM AND LIP FORM: Direct rim and a rounded, exterior folded lip

CORE COLOR: B (fired and cooled in a reducing environment)

INTERIOR SURFACE COLOR: very dark grayish-brown

EXTERIOR SURFACE COLOR: very dark grayish-brown

WALL THICKNESS (RIM, BODY, AND BASE IN MM): rim, $6.8 \mathrm{~mm}$

INTERIOR SURFACE TREATMENT: smoothed

EXTERIOR SURFACE TREATMENT: burnished

HEIGHT (IN CM): 7.0

ORIFICE DIAMETER (IN CM): 15.0

DIAMETER AT BOTTOM OF RIM OR NECK (IN CM): 14.8

BASE DIAMETER (IN CM) AND SHAPE OF BASE: 7.2, circular and flat 


\section{ESTIMATED VOLUME (IN LITERS): 0.6}

DECORATION (INCLUDING MOTIF AND ELEMENTS WHEN APPARENT): The rim panel has a roughly executed engraved motif of horizontal interlocking scrolls (repeated four times) (Figure 1). The interlocking scrolls are divided by near-vertical lines as well as sets of curvilinear lines, and the areas above and below the scrolls have sets of vertical lines, curvilinear lines, rectilinear, and diagonal lines.

PIGMENT USE AND LOCATION ON VESSEL: red in engraved lines

TYPE AND VARIETY [IF KNOWN]: Ripley Engraved, var. unspecified

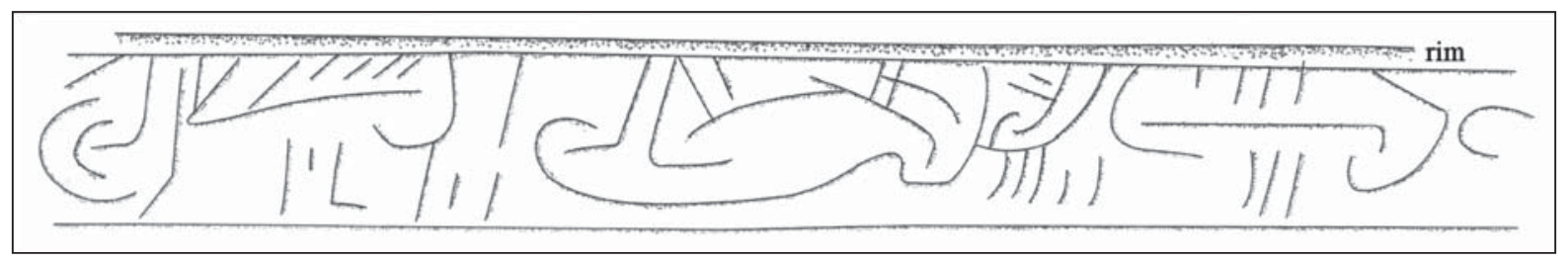

Figure 1. Engraved motif on Burial 1, Vessel 1 from the Holly Lake Ranch site.

\section{GOLDSMITH (41WD208) VESSELS}

The Goldsmith site is a late (ca. post-A.D. 1550) Titus phase habitation site and cemetery on Dry Creek in the Lake Fork Creek basin (Perttula et al. 1993:139 and Figure 4). Two ancestral Caddo burials were excavated from the site in 1985 before the area could be disturbed by ongoing pothunting activities. Burial 1 contained seven ceramic vessels (Perttula et al. 1993:Figure 8) and Burial 2 had nine ceramic vessels as funerary offerings (Perttula 1993:Figure 9).

SITE NAME OR SITE NUMBER: Goldsmith (41WD208)

VESSEL NO.: Burial 1, Vessel 1

NON-PLASTICS AND PASTE: grog

VESSEL FORM: Jar

RIM AND LIP FORM: Everted rim and rounded lip

CORE COLOR: $\mathrm{G}$ (fired in a reducing environment and cooled in the open air)

INTERIOR SURFACE COLOR: very dark grayish-brown

EXTERIOR SURFACE COLOR: yellowish-brown; fire clouds on the body and base; organic residue on the rim and body

WALL THICKNESS (RIM, BODY, AND BASE IN MM): rim, 6.6 mm

INTERIOR SURFACE TREATMENT: smoothed

EXTERIOR SURFACE TREATMENT: smoothed on the body 
HEIGHT (IN CM): 21.6

ORIFICE DIAMETER (IN CM): 15.0

DIAMETER AT BOTTOM OF RIM OR NECK (IN CM): 13.6

BASE DIAMETER (IN CM) AND SHAPE OF BASE: 8.0; circular and rounded

ESTIMATED VOLUME (IN LITERS): 2.9

DECORATION (INCLUDING MOTIF AND ELEMENTS WHEN APPARENT): The primary decorative element on the rim is cross-hatched incised lines. Below the lip and at the rim-body juncture are single horizontal rows of tool punctations (Figure 2). There are also four equally-spaced appliqued nodes under the vessel lip. The vessel body has four large triangular areas created by diagonal appliqued ridges. Within each of the triangular areas is a single vertical incised line and opposing sets of short diagonal incised lines. Between each of the triangular appliqued areas is a single vertical appliqued ridge; the three appliqued ridges merge as a large appliqued node at the rim-body juncture (Figure 2).

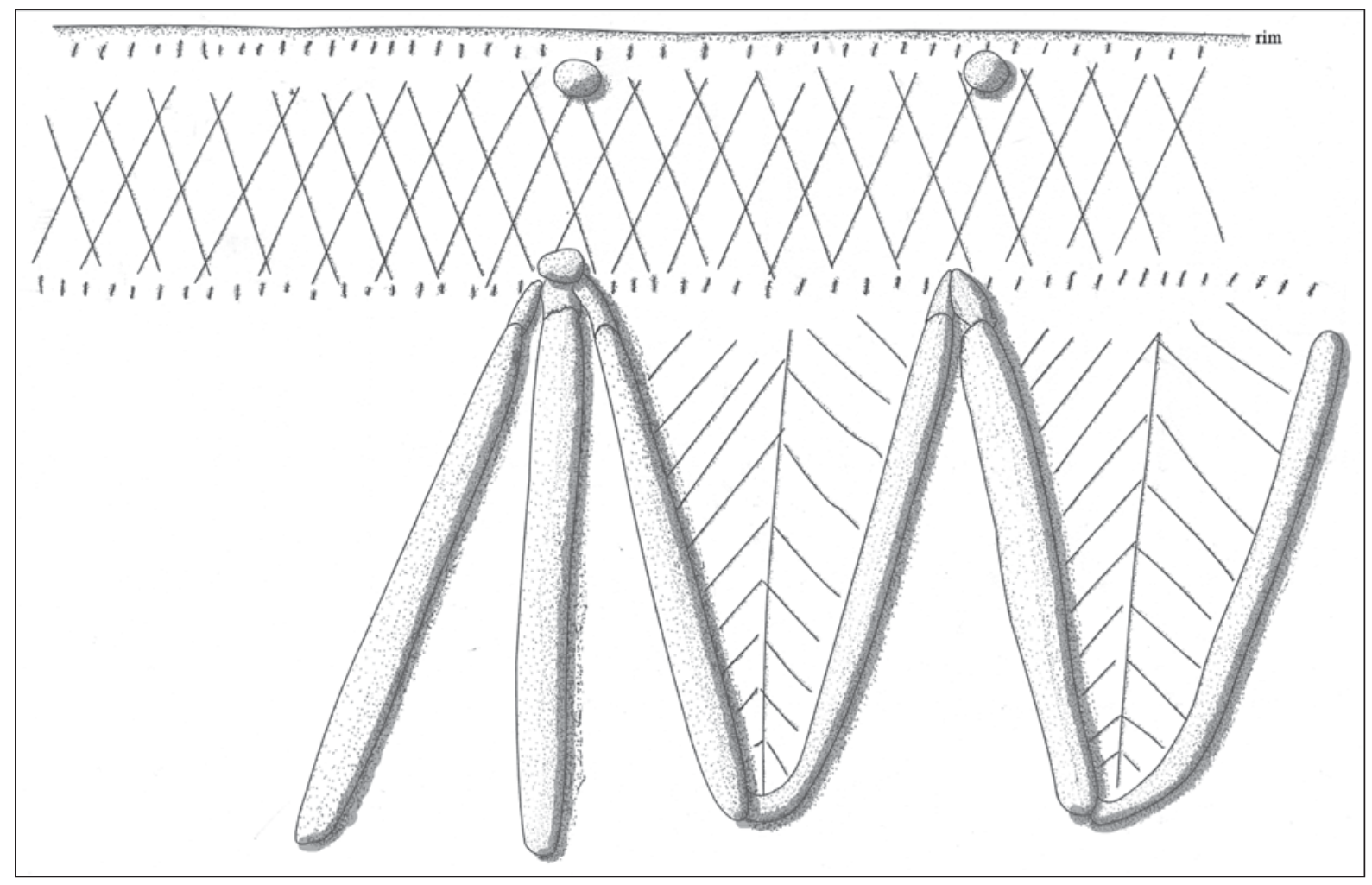

Figure 2. Decorative elements on cf. Maydelle Incised jar (Burial 1, Vessel 2) from the Goldsmith site.

PIGMENT USE AND LOCATION ON VESSEL: none

TYPE AND VARIETY [IF KNOWN]: cf. Maydelle Incised 
SITE NAME OR SITE NUMBER: Goldsmith (41WD208)

VESSEL NO.: Burial 1, Vessel 2

NON-PLASTICS AND PASTE: grog

VESSEL FORM: Carinated bowl

RIM AND LIP FORM: Direct rim and a flat, exterior folded lip

CORE COLOR: $\mathrm{H}$ (fired in a reducing environment and cooled in the open air)

INTERIOR SURFACE COLOR: dark yellowish-brown

EXTERIOR SURFACE COLOR: grayish-brown

WALL THICKNESS (RIM, BODY, AND BASE IN MM): rim, $5.0 \mathrm{~mm}$

INTERIOR SURFACE TREATMENT: smoothed

EXTERIOR SURFACE TREATMENT: burnished

HEIGHT (IN CM): 6.6

ORIFICE DIAMETER (IN CM): 14.3

DIAMETER AT BOTTOM OF RIM OR NECK (IN CM): 14.0

BASE DIAMETER (IN CM) AND SHAPE OF BASE: 6.0, circular and flat

ESTIMATED VOLUME (IN LITERS): 0.6

DECORATION (INCLUDING MOTIF AND ELEMENTS WHEN APPARENT): The rim panel has an engraved alternate nested triangle motif repeated four times around the vessels. The four upper and four lower nested triangles each have a series of small excised or cross-hatched bracket and triangular elements that have created three negative ovals within each triangle motif (Figure 3).

PIGMENT USE AND LOCATION ON VESSEL: white pigment in the engraved lines.

TYPE AND VARIETY [IF KNOWN]: Ripley Engraved, var. Williams (see Perttula et al. 2012:Figure 9h)

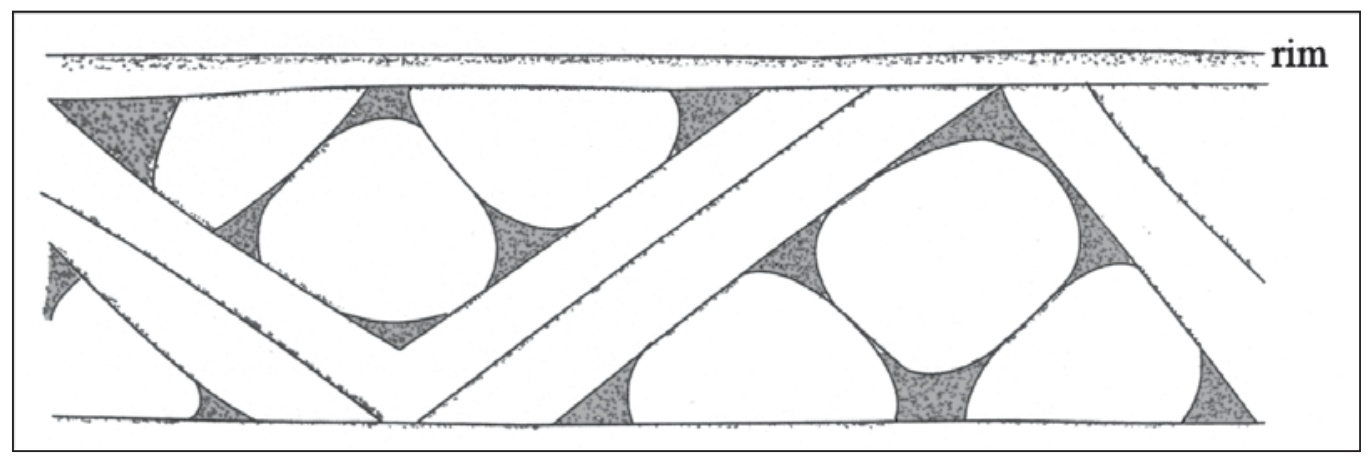

Figure 3. Decorative elements on Ripley Engraved, var. Williams carinated bowl (Burial 1, Vessel 2) from the Goldsmith site. 
SITE NAME OR SITE NUMBER: Goldsmith (41WD208)

VESSEL NO.: Burial 1, Vessel 3

NON-PLASTICS AND PASTE: grog

VESSEL FORM: Carinated bowl

RIM AND LIP FORM: Direct rim and a rounded, exterior folded lip

CORE COLOR: $\mathrm{F}$ (fired in a reducing environment and cooled in the open air)

INTERIOR SURFACE COLOR: dark yellowish-brown; fire clouds on the base

EXTERIOR SURFACE COLOR: yellowish-brown; fire clouds on the rim, body, and the base

WALL THICKNESS (RIM, BODY, AND BASE IN MM): rim, 7.3 mm

INTERIOR SURFACE TREATMENT: smoothed

EXTERIOR SURFACE TREATMENT: burnished

HEIGHT (IN CM): 13.7

ORIFICE DIAMETER (IN CM): 25.4

DIAMETER AT BOTTOM OF RIM OR NECK (IN CM): 25.0

BASE DIAMETER (IN CM) AND SHAPE OF BASE: 9.0; circular and flat

ESTIMATED VOLUME (IN LITERS): 3.1

DECORATION (INCLUDING MOTIF AND ELEMENTS WHEN APPARENT): The rim panel has an engraved scroll and circle motif repeated four times around the vessel (Figure 4). The central circle element has an outer arc of two curvilinear lines as well as a small central excised dot. The scroll fill zones have a series of excised brackets that have created negative oval and triangular-shaped areas within the fill zones.

PIGMENT USE AND LOCATION ON VESSEL: red pigment in engraved lines

TYPE AND VARIETY [IF KNOWN]: Ripley Engraved, var. Galt (see Perttula et al. 2012:Figure 9c)

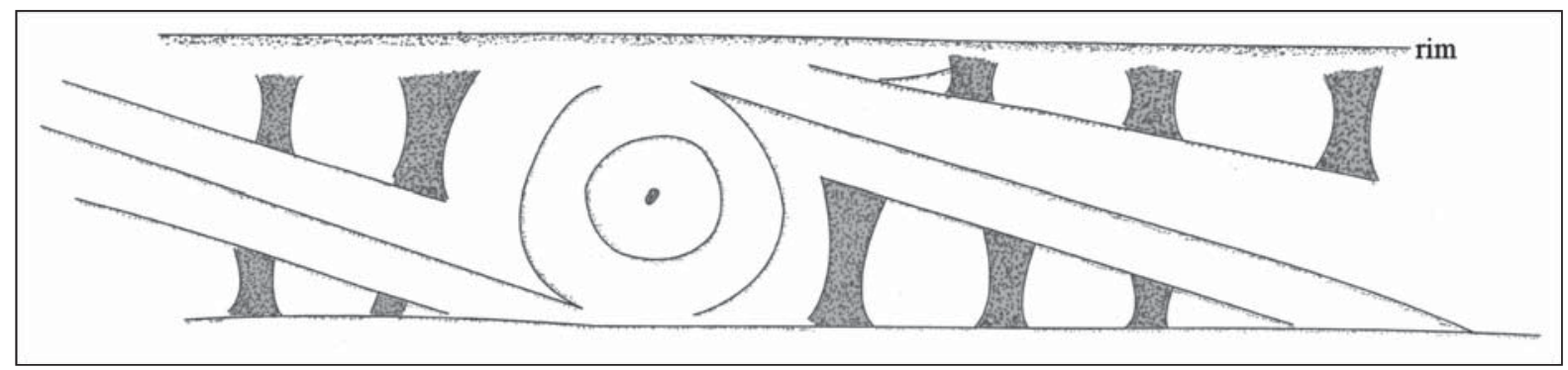

Figure 4. Decorative elements on Ripley Engraved, var. Galt carinated bowl (Burial 1, Vessel 3) from the Goldsmith site. 
SITE NAME OR SITE NUMBER: Goldsmith (41WD208)

VESSEL NO.: Burial 1, Vessel 4

NON-PLASTICS AND PASTE: grog

VESSEL FORM: Carinated bowl

RIM AND LIP FORM: Direct rim and rounded, exterior folded lip

CORE COLOR: $\mathrm{F}$ (fired in a reducing environment and cooled in the open air)

INTERIOR SURFACE COLOR: yellowish-brown

EXTERIOR SURFACE COLOR: yellowish-brown; fire clouds on the rim and body

WALL THICKNESS (RIM, BODY, AND BASE IN MM): rim, 7.0 mm; body, 8.9 mm; base, $9.4 \mathrm{~mm}$

INTERIOR SURFACE TREATMENT: smoothed

EXTERIOR SURFACE TREATMENT: burnished

HEIGHT (IN CM): 13.0

ORIFICE DIAMETER (IN CM): 25.0

DIAMETER AT BOTTOM OF RIM OR NECK (IN CM): 24.8

BASE DIAMETER (IN CM) AND SHAPE OF BASE: circular and flat

ESTIMATED VOLUME (IN LITERS): 2.9

DECORATION (INCLUDING MOTIF AND ELEMENTS WHEN APPARENT): The rim panel has an engraved scroll and circle motif repeated four times around the vessel. The central circle has a circle and a cross element, and there are curvilinear arcing lines on either side of the circle and cross element (Figure 5); the slanting scroll lines begin at these arcing engraved lines. The upper and lower scroll fill zones have cross-hatched engraved brackets and a single vertical line, creating negative two ovals within the fill zones as well as an open triangular area.

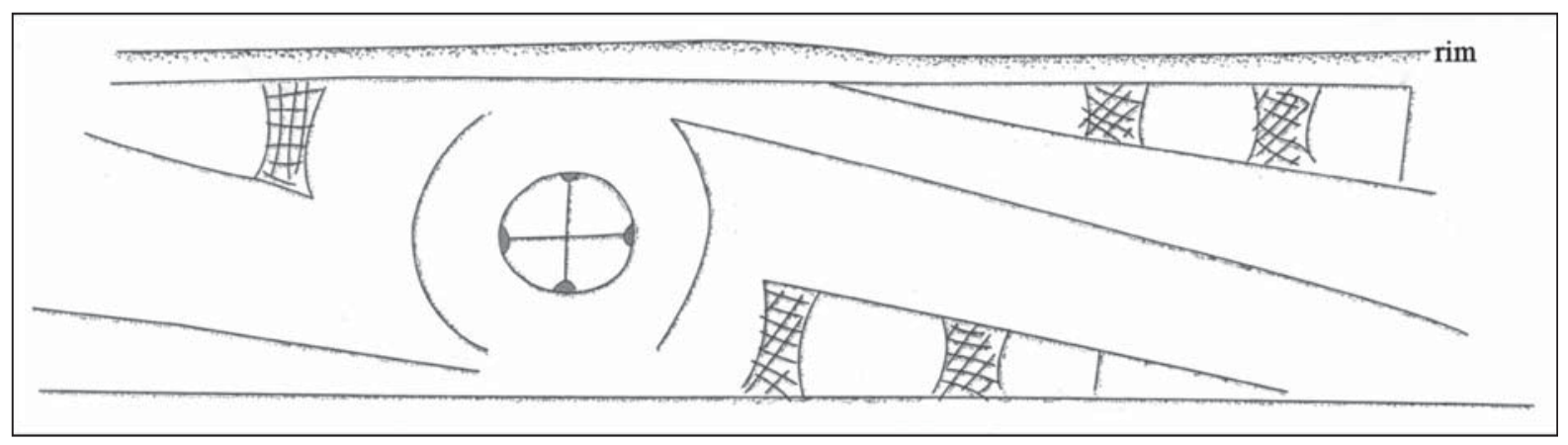

Figure 5. Decorative elements on Ripley Engraved, var. Galt carinated bowl (Burial 1, Vessel 4) from the Goldsmith site. 
PIGMENT USE AND LOCATION ON VESSEL: red pigment in engraved lines

TYPE AND VARIETY [IF KNOWN]: Ripley Engraved, var. Galt (see Perttula et al. 2012:Figure 9c).

SITE NAME OR SITE NUMBER: Goldsmith (41WD208)

VESSEL NO.: Burial 1, Vessel 5

NON-PLASTICS AND PASTE: grog

VESSEL FORM: Jar with four rim peaks

RIM AND LIP FORM: Everted rim and rounded lip

CORE COLOR: G (fired in a reducing environment and cooled in the open air)

INTERIOR SURFACE COLOR: very dark grayish-brown

EXTERIOR SURFACE COLOR: yellowish-brown; organic residue on the vessel body

WALL THICKNESS (RIM, BODY, AND BASE IN MM): rim, $7.5 \mathrm{~mm}$

INTERIOR SURFACE TREATMENT: smoothed

EXTERIOR SURFACE TREATMENT: smoothed on the vessel body

HEIGHT (IN CM): $27.5 ; 28.0 \mathrm{~cm}$ at the rim peaks

ORIFICE DIAMETER (IN CM): 25.0

DIAMETER AT BOTTOM OF RIM OR NECK (IN CM): 20.6

BASE DIAMETER (IN CM) AND SHAPE OF BASE: 8.1; circular and flat

ESTIMATED VOLUME (IN LITERS): 9.0

DECORATION (INCLUDING MOTIF AND ELEMENTS WHEN APPARENT): The rim has seven horizontal rows of neck banded coils. Underneath each of the rim peaks are pseudo-lug handles $(2.5 \times 2.5 \mathrm{~cm}$ in length and width) comprised of three short appliqued ridges. There are also four vertical appliqued ridges on the vessel body; they extend from the rim-body juncture $14.5 \mathrm{~cm}$ down the vessel body (Figure 6). These vertical appliqued ridges are aligned with the rim peaks and the appliqued lug handles.

PIGMENT USE AND LOCATION ON VESSEL: none

TYPE AND VARIETY [IF KNOWN]: La Rue Neck Banded

SITE NAME OR SITE NUMBER: Goldsmith (41WD208)

VESSEL NO.: Burial 1, Vessel 6 


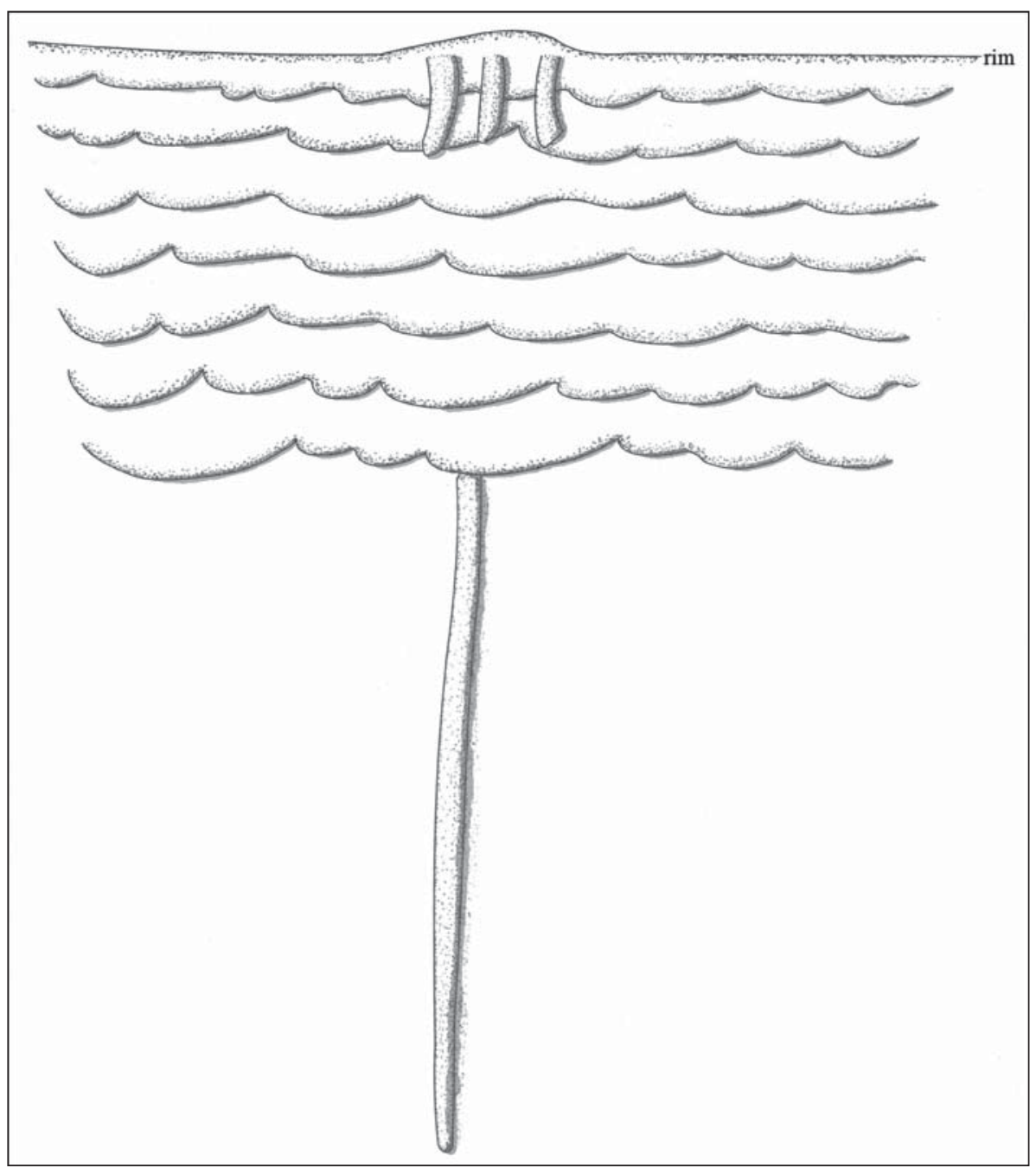

Figure 6. La Rue Neck Banded jar (Burial 1, Vessel 5) from the Goldsmith site.

NON-PLASTICS AND PASTE: grog

VESSEL FORM: Carinated bowl

RIM AND LIP FORM: Direct rim and rounded, exterior folded lip

CORE COLOR: F (fired in a reducing environment and cooled in the open air)

INTERIOR SURFACE COLOR: dark yellowish-brown; fire clouds on the vessel body and base EXTERIOR SURFACE COLOR: dark yellowish-brown; fire clouds on the vessel body and base WALL THICKNESS (RIM, BODY, AND BASE IN MM): rim, 5.9 mm INTERIOR SURFACE TREATMENT: smoothed EXTERIOR SURFACE TREATMENT: burnished 
HEIGHT (IN CM): 7.8

ORIFICE DIAMETER (IN CM): 15.5

DIAMETER AT BOTTOM OF RIM OR NECK (IN CM): 15.3

BASE DIAMETER (IN CM) AND SHAPE OF BASE: 7.0; circular and flat

ESTIMATED VOLUME (IN LITERS): 0.7

DECORATION (INCLUDING MOTIF AND ELEMENTS WHEN APPARENT): The rim panel has an engraved scroll and circle motif repeated four times around the vessel. The central circle has a circle and a cross element with excised ends, and there are curvilinear arcing lines on either side of the circle and cross element (Figure 7). The slanting scroll lines are free-standing, and they are not attached to the circle elements. The upper and lower scroll fill zones have excised brackets and a single vertical line, creating negative ovals within the fill zones.

PIGMENT USE AND LOCATION ON VESSEL: white pigment in engraved lines

TYPE AND VARIETY [IF KNOWN]: Ripley Engraved, var. Galt (see Perttula et al. 2012:Figure 9c).

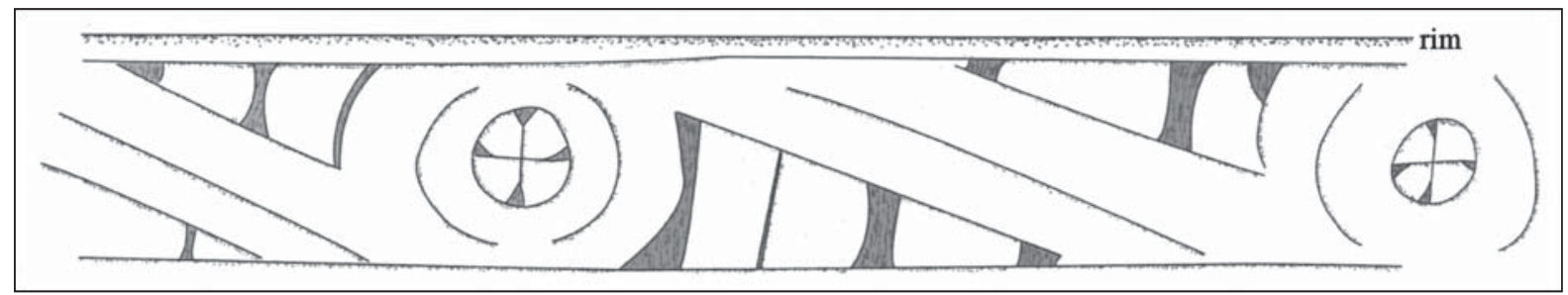

Figure 7. Decorative elements on Ripley Engraved, var. Galt carinated bowl (Burial 1, Vessel 6) from the Goldsmith site.

SITE NAME OR SITE NUMBER: Goldsmith (41WD208)

VESSEL NO.: Burial 1, Vessel 7

NON-PLASTICS AND PASTE: grog

VESSEL FORM: Bottle

RIM AND LIP FORM: Direct rim and rounded lip

CORE COLOR: F (fired in a reducing environment and cooled in the open air)

INTERIOR SURFACE COLOR: yellowish-brown

EXTERIOR SURFACE COLOR: yellowish-brown

WALL THICKNESS (RIM, BODY, AND BASE IN MM): rim, $4.5 \mathrm{~mm}$

INTERIOR SURFACE TREATMENT: none 
EXTERIOR SURFACE TREATMENT: burnished

HEIGHT (IN CM): 25.8

ORIFICE DIAMETER (IN CM): 5.3

DIAMETER AT BOTTOM OF RIM OR NECK (IN CM): 6.5; maximum body width of $16.8 \mathrm{~cm}$

BASE DIAMETER (IN CM) AND SHAPE OF BASE: 8.0; circular and flat

ESTIMATED VOLUME (IN LITERS): 0.8

DECORATION (INCLUDING MOTIF AND ELEMENTS WHEN APPARENT): The vessel body has an engraved motif repeated four times around the vessel; the motif is outlined by two upper and two lower horizontal engraved lines. The engraved motif consists of interlocking curvilinear scrolls that meet at a central cross-hatched circle (Figure 8). The scroll line closest to, and above, the central circle has a wider cross-hatched zone. On all four sides of each interlocking scroll motif are triangular elements with two cross-hatched corners.

PIGMENT USE AND LOCATION ON VESSEL: red pigment in engraved lines

TYPE AND VARIETY [IF KNOWN]: Wilder Engraved, var. Wilder (see Perttula et al. 2012:Figure 11a-c).

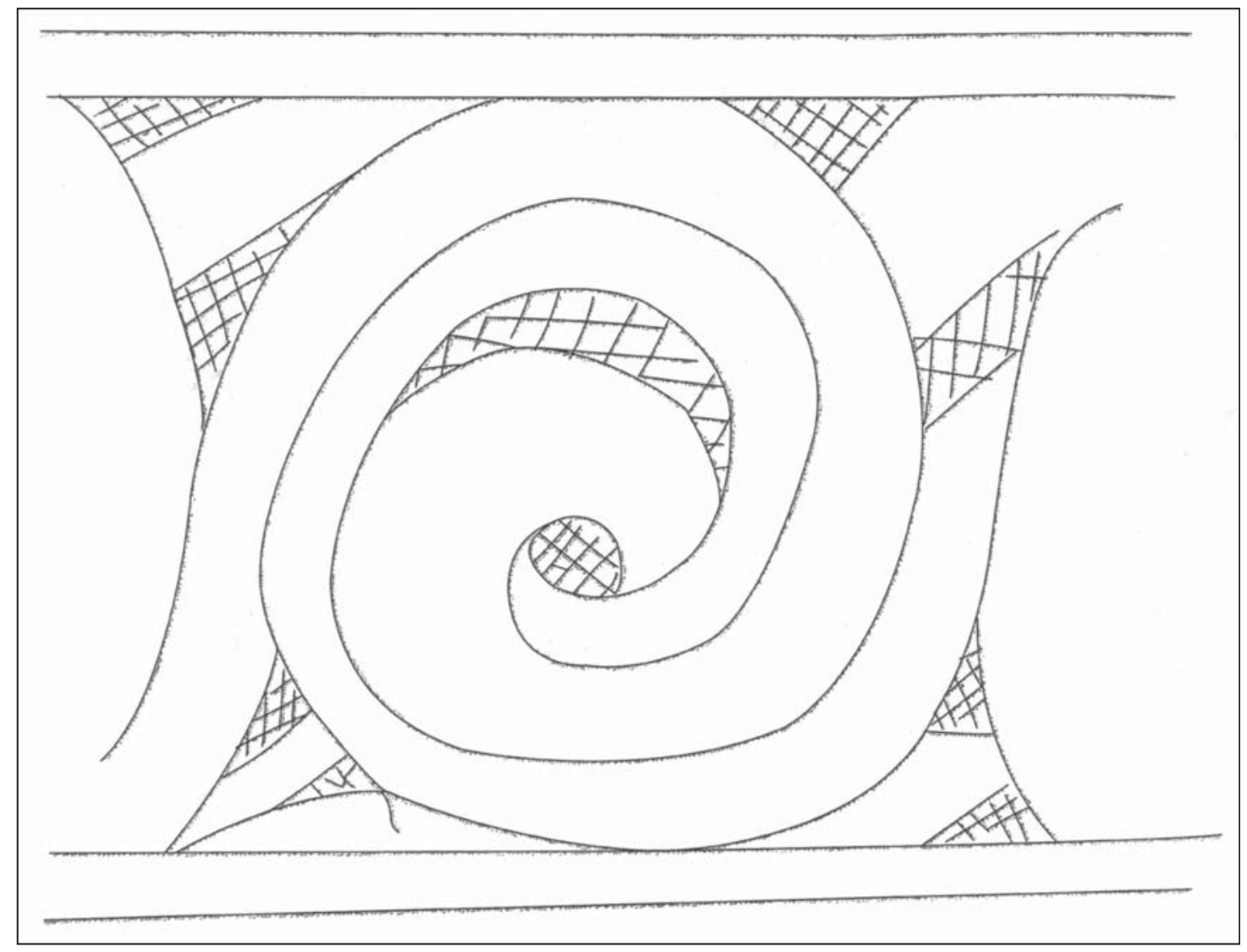

Figure 8. Decorative elements on Wilder Engraved, var. Wilder bottle (Burial 1, Vessel 7) from the Goldsmith site. 
SITE NAME OR SITE NUMBER: Goldsmith (41WD208)

VESSEL NO.: Burial 2, Vessel 1

NON-PLASTICS AND PASTE: grog

VESSEL FORM: Carinated bowl

RIM AND LIP FORM: Direct rim and rounded lip

CORE COLOR: $\mathrm{H}$ (fired in a reducing environment and cooled in the open air)

INTERIOR SURFACE COLOR: yellowish-brown

EXTERIOR SURFACE COLOR: dark grayish-brown

WALL THICKNESS (RIM, BODY, AND BASE IN MM): rim, 6.4 mm

INTERIOR SURFACE TREATMENT: smoothed

EXTERIOR SURFACE TREATMENT: burnished

HEIGHT (IN CM): 17.8

ORIFICE DIAMETER (IN CM): 26.3

DIAMETER AT BOTTOM OF RIM OR NECK (IN CM): 26.1

BASE DIAMETER (IN CM) AND SHAPE OF BASE: 9.7; circular and flat

ESTIMATED VOLUME (IN LITERS): 4.1

DECORATION (INCLUDING MOTIF AND ELEMENTS WHEN APPARENT): The rim panel has an engraved horizontal interlocking scroll motif repeated four times around the vessel (Figure 9). The upper and lower horizontal scrolls are interlocked by two sets of curvilinear excised zones (each with a small projecting spur), and demarcated by single curvilinear excised zones that extend from the rim to the vessel carination. Each of these zones has a single spur.

PIGMENT USE AND LOCATION ON VESSEL: none

TYPE AND VARIETY [IF KNOWN]: Ripley Engraved, var. Pilgrims (see Perttula et al. 2012:Figure 9g)

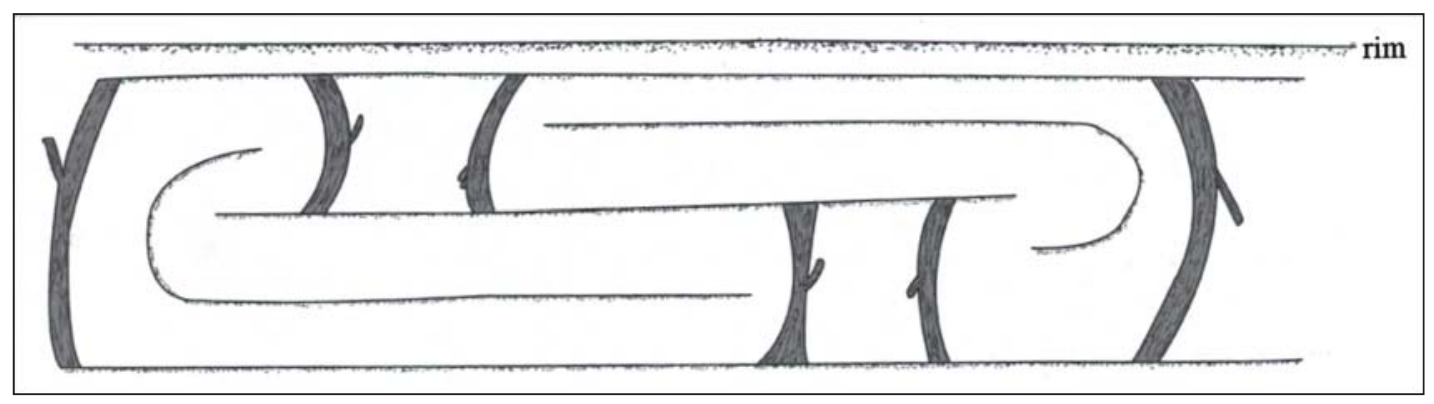

Figure 9. Decorative elements on Ripley Engraved, var. Pilgrims carinated bowl (Burial 2, Vessel 1) from the Goldsmith site. 
SITE NAME OR SITE NUMBER: Goldsmith (41WD208)

VESSEL NO.: Burial 2, Vessel 2

NON-PLASTICS AND PASTE: grog

VESSEL FORM: Carinated bowl

RIM AND LIP FORM: Direct rim and a rounded, exterior folded lip

CORE COLOR: $\mathrm{F}$ (fired in a reducing environment and cooled in the open air)

INTERIOR SURFACE COLOR: yellowish-brown to dark yellowish-brown; fire clouds on the base

EXTERIOR SURFACE COLOR: yellowish-brown; fire clouds on the body and base

WALL THICKNESS (RIM, BODY, AND BASE IN MM): rim, $4.0 \mathrm{~mm}$

INTERIOR SURFACE TREATMENT: smoothed

EXTERIOR SURFACE TREATMENT: burnished

HEIGHT (IN CM): 7.8

ORIFICE DIAMETER (IN CM): 17.9

DIAMETER AT BOTTOM OF RIM OR NECK (IN CM): 17.5

BASE DIAMETER (IN CM) AND SHAPE OF BASE: 7.0; circular and flat

ESTIMATED VOLUME (IN LITERS): 0.8

DECORATION (INCLUDING MOTIF AND ELEMENTS WHEN APPARENT): The exterior vessel surface is plain, but there is a single horizontal engraved line on the interior vessel surface at the carination.

PIGMENT USE AND LOCATION ON VESSEL: none

TYPE AND VARIETY [IF KNOWN]: Unidentified fine ware

SITE NAME OR SITE NUMBER: Goldsmith (41WD208)

VESSEL NO.: Burial 2, Vessel 3

NON-PLASTICS AND PASTE: grog

VESSEL FORM: Carinated bowl

RIM AND LIP FORM: Direct rim and rounded lip

CORE COLOR: $\mathrm{G}$ (fired in a reducing environment and cooled in the open air) 
INTERIOR SURFACE COLOR: dark grayish-brown

EXTERIOR SURFACE COLOR: dark yellowish-brown to dark grayish-brown

WALL THICKNESS (RIM, BODY, AND BASE IN MM): rim, 4.3 mm

INTERIOR SURFACE TREATMENT: smoothed

EXTERIOR SURFACE TREATMENT: burnished

HEIGHT (IN CM): 9.0

ORIFICE DIAMETER (IN CM): 15.3

DIAMETER AT BOTTOM OF RIM OR NECK (IN CM): 15.3

BASE DIAMETER (IN CM) AND SHAPE OF BASE: 6.4; circular and flat

ESTIMATED VOLUME (IN LITERS): 0.8

DECORATION (INCLUDING MOTIF AND ELEMENTS WHEN APPARENT): The rim panel has an engraved continuous scroll motif; the central scroll line is curvilinear rather than vertical and slanting (see Perttula et al. 2012:Figure 9f). The upper and lower scroll fill zones have hatched brackets and triangles, creating a series of two or three negative ovals within the scroll fill zones (Figure 10).

PIGMENT USE AND LOCATION ON VESSEL: red pigment in engraved lines

TYPE AND VARIETY [IF KNOWN]: cf. Ripley Engraved, var. Carpenter (see Perttula et al. 2012:Figure 9f).

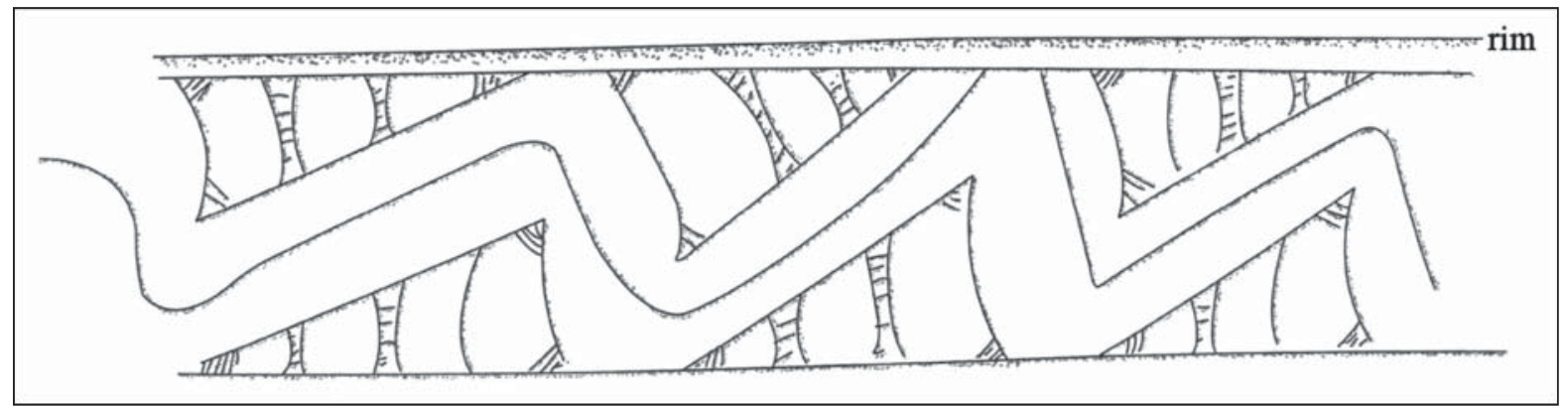

Figure 10. Decorative elements on cf. Ripley Engraved, var. Carpenter carinated bowl (Burial 2, Vessel 3) from the Goldsmith site.

SITE NAME OR SITE NUMBER: Goldsmith (41WD208)

VESSEL NO.: Burial 2, Vessel 4

NON-PLASTICS AND PASTE: grog

VESSEL FORM: Bottle with a squat body

RIM AND LIP FORM: Direct rim and rounded lip 
CORE COLOR: $\mathrm{F}$ (fired in a reducing environment and cooled in the open air)

INTERIOR SURFACE COLOR: yellowish-brown

EXTERIOR SURFACE COLOR: yellowish-brown

WALL THICKNESS (RIM, BODY, AND BASE IN MM): rim, 5.4 mm

INTERIOR SURFACE TREATMENT: none

EXTERIOR SURFACE TREATMENT: burnished

HEIGHT (IN CM): 24.0

ORIFICE DIAMETER (IN CM): 4.5

DIAMETER AT BOTTOM OF RIM OR NECK (IN CM): 6.4; maximum body width is $19.3 \mathrm{~cm}$

BASE DIAMETER (IN CM) AND SHAPE OF BASE: 8.5, circular and flat

ESTIMATED VOLUME (IN LITERS): 0.8

DECORATION (INCLUDING MOTIF AND ELEMENTS WHEN APPARENT): The vessel body has an engraved motif repeated four times around the vessel; the motif is outlined by three upper and two lower horizontal engraved lines. The engraved motif consists of vertical interlocking curvilinear scrolls that meet at a central hatched circle (Figure 11). The scroll lines closest to the central circle have wider hatched zones. On all four sides of each interlocking scroll motif are triangular elements with three cross-hatched corners. There is a also a single free-standing curvilinear engraved line that hooks around the central scroll and circle elements.

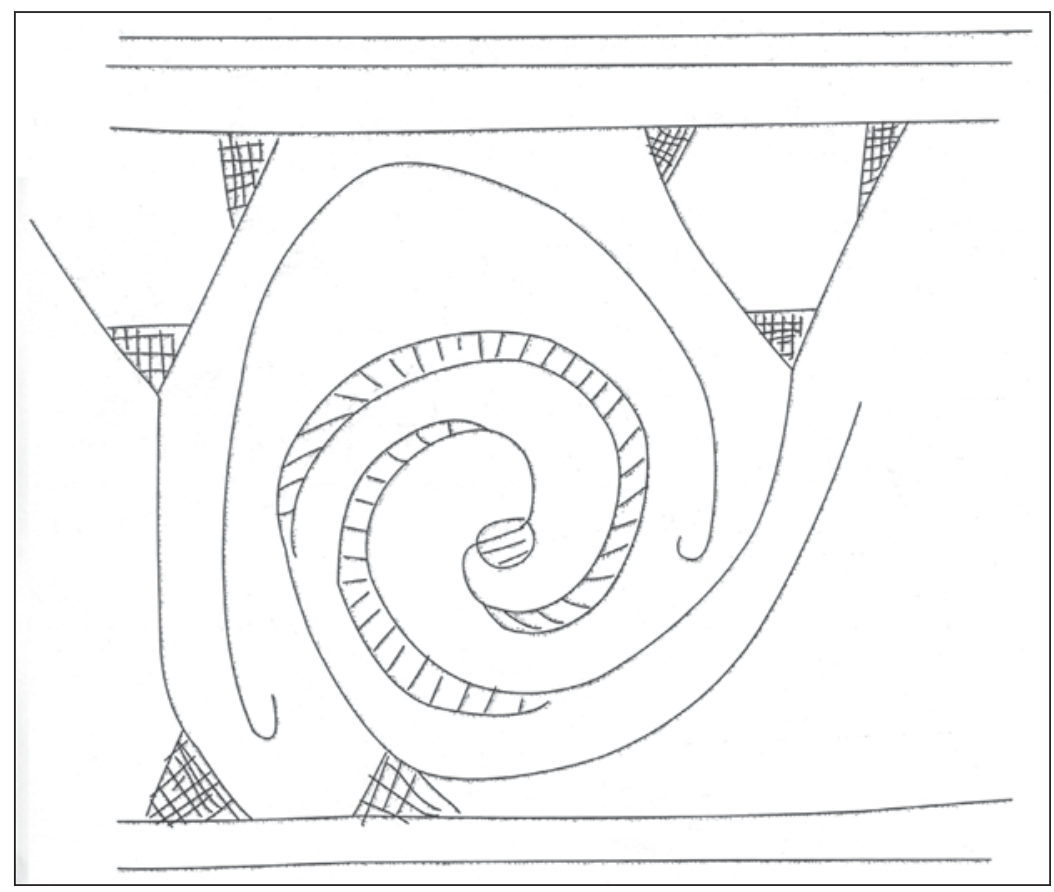

Figure 11. Decorative elements on Wilder Engraved, var. Wilder bottle (Burial 2, Vessel 4) from the Goldsmith site. 
PIGMENT USE AND LOCATION ON VESSEL: none

TYPE AND VARIETY [IF KNOWN]: Wilder Engraved, var. Wilder (see Perttula et al. 2012:Figure 11a-c)

SITE NAME OR SITE NUMBER: Goldsmith (41WD208)

VESSEL NO.: Burial 2, Vessel 5

NON-PLASTICS AND PASTE: grog

VESSEL FORM: Carinated bowl

RIM AND LIP FORM: Direct rim and rounded, exterior folded lip

CORE COLOR: F (fired in a reducing environment and cooled in the open air)

INTERIOR SURFACE COLOR: dark yellowish-brown

EXTERIOR SURFACE COLOR: dark yellowish-brown; fire clouds on the vessel body

WALL THICKNESS (RIM, BODY, AND BASE IN MM): rim, 7.4 mm

INTERIOR SURFACE TREATMENT: smoothed

EXTERIOR SURFACE TREATMENT: burnished

HEIGHT (IN CM): 13.6

ORIFICE DIAMETER (IN CM): 27.3

DIAMETER AT BOTTOM OF RIM OR NECK (IN CM): 27.0

BASE DIAMETER (IN CM) AND SHAPE OF BASE: 8.0; circular and flat

ESTIMATED VOLUME (IN LITERS): 3.4

DECORATION (INCLUDING MOTIF AND ELEMENTS WHEN APPARENT): The rim panel has an engraved scroll and circle motif that is repeated four times around the vessel. The central circle element has a smaller circle and cross element (with excised ends) within it. The upper and lower scroll fill zones have cross-hatched brackets and excised triangular and rectangular elements that have created a series of two or three negative ovals within the scroll fill zones (Figure 12).

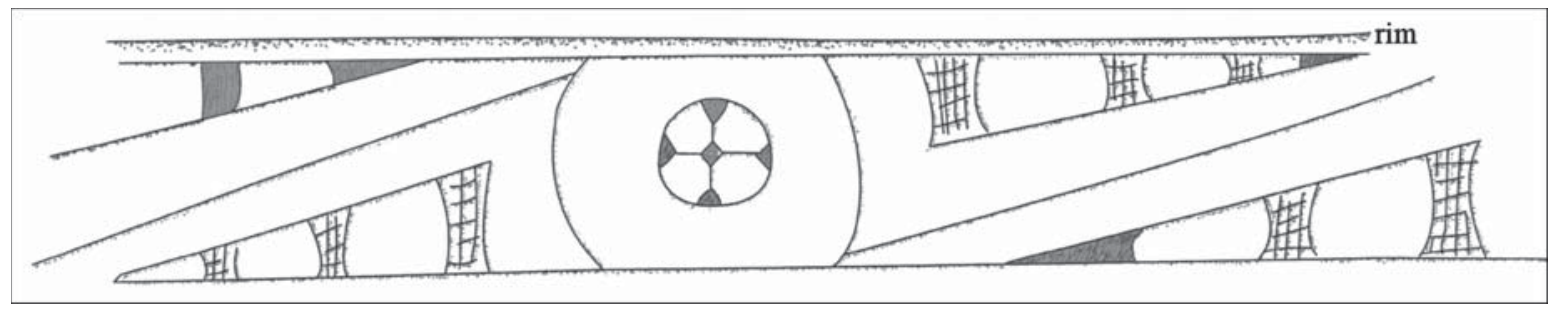

Figure 12. Decorative elements on Ripley Engraved, var. Galt carinated bowl (Burial 2, Vessel 5) from the Goldsmith site. 
PIGMENT USE AND LOCATION ON VESSEL: white in engraved lines

TYPE AND VARIETY [IF KNOWN]: Ripley Engraved, var. Galt (see Perttula et al. 2012:Figure 9c)

SITE NAME OR SITE NUMBER: Goldsmith (41WD208)

VESSEL NO.: Burial 2, Vessel 6

NON-PLASTICS AND PASTE: grog

VESSEL FORM: Carinated bowl

RIM AND LIP FORM: Direct rim and rounded, exterior folded lip

CORE COLOR: $\mathrm{F}$ (fired in a reducing environment and cooled in the open air)

INTERIOR SURFACE COLOR: yellowish-brown

EXTERIOR SURFACE COLOR: yellowish-brown; fire clouds on vessel body

WALL THICKNESS (RIM, BODY, AND BASE IN MM): rim, $5.3 \mathrm{~mm}$; body, $5.6 \mathrm{~mm}$; base, $6.9 \mathrm{~mm}$

INTERIOR SURFACE TREATMENT: smoothed

EXTERIOR SURFACE TREATMENT: burnished

HEIGHT (IN CM): 14.5

ORIFICE DIAMETER (IN CM): 30.0

DIAMETER AT BOTTOM OF RIM OR NECK (IN CM): 29.7

BASE DIAMETER (IN CM) AND SHAPE OF BASE: 8.0; circular and flat

ESTIMATED VOLUME (IN LITERS): 3.9

DECORATION (INCLUDING MOTIF AND ELEMENTS WHEN APPARENT): The rim panel has an engraved circle, slanted scroll, and nested triangle motif repeated four times around the vessel (Figure 13).

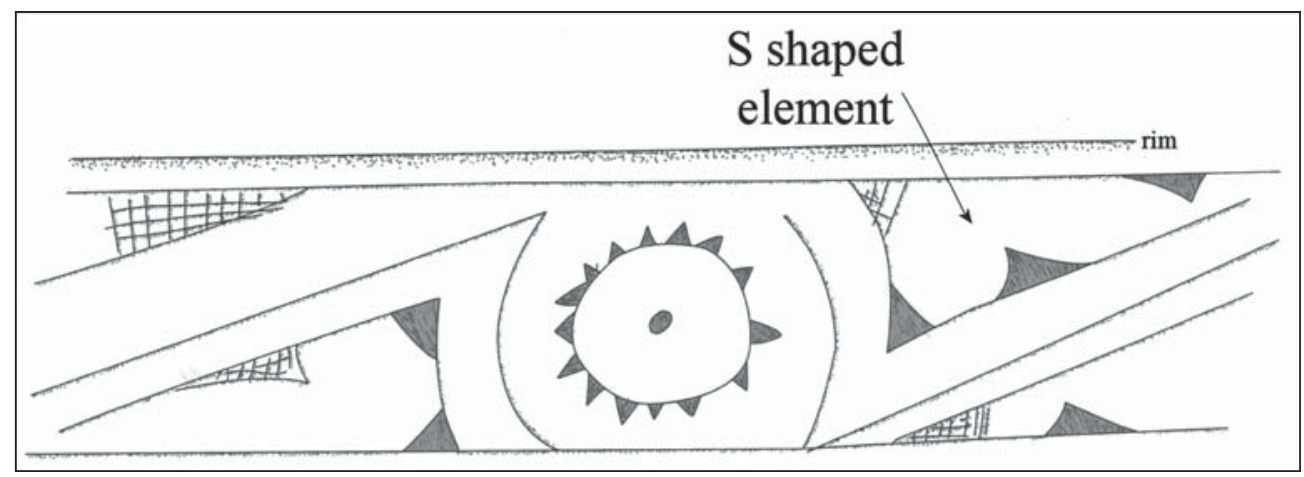

Figure 13. Decorative elements on cf. Ripley Engraved, var. Cash carinated bowl (Burial 2, Vessel 6) from the Goldsmith site. 
The central circle element is ringed by a continuous series of small excised pendant triangles; there is a small excised dot at the center of the circle. The upper and lower triangular-shaped scroll fill zones have negative $\mathrm{S}$-shaped elements outlined by small excised or cross-hatched triangular elements.

PIGMENT USE AND LOCATION ON VESSEL: white pigment in engraved lines

TYPE AND VARIETY [IF KNOWN]: cf. Ripley Engraved, var. Cash (see Perttula et al. 2012:Figure 9e)

SITE NAME OR SITE NUMBER: Goldsmith (41WD208)

VESSEL NO.: Burial 2, Vessel 7

NON-PLASTICS AND PASTE: grog

VESSEL FORM: Jar with four rim peaks

RIM AND LIP FORM: Everted rim and rounded, exterior folded lip

CORE COLOR: $\mathrm{G}$ (fired in a reducing environment and cooled in the open air)

INTERIOR SURFACE COLOR: very dark grayish-brown

EXTERIOR SURFACE COLOR: reddish-brown; fire clouds on the rim, body, and base

WALL THICKNESS (RIM, BODY, AND BASE IN MM): rim, $7.2 \mathrm{~mm}$

INTERIOR SURFACE TREATMENT: smoothed

EXTERIOR SURFACE TREATMENT: none

HEIGHT (IN CM): 19.5

ORIFICE DIAMETER (IN CM): 15.8

DIAMETER AT BOTTOM OF RIM OR NECK (IN CM): 15.3

BASE DIAMETER (IN CM) AND SHAPE OF BASE: 9.0; circular and flat

ESTIMATED VOLUME (IN LITERS): 2.0

DECORATION (INCLUDING MOTIF AND ELEMENTS WHEN APPARENT): The rim has four horizontal rows of neck banded coils. Under each rim peak are three closely spaced ( $2.0 \times 2.0 \mathrm{~cm}$ in length and width) appliqued ridges, perhaps a pseudo-lug handle. The vessel body is decorated with four appliqued ridge triangles that are pendant from the rim-body juncture (Figure 14). Inside each of these appliqued triangles are a series of diagonal opposed appliqued ridges. There are also small and separate appliqued ridge elements that encircle the rim-body juncture.

PIGMENT USE AND LOCATION ON VESSEL: none

TYPE AND VARIETY [IF KNOWN]: La Rue Neck Banded 


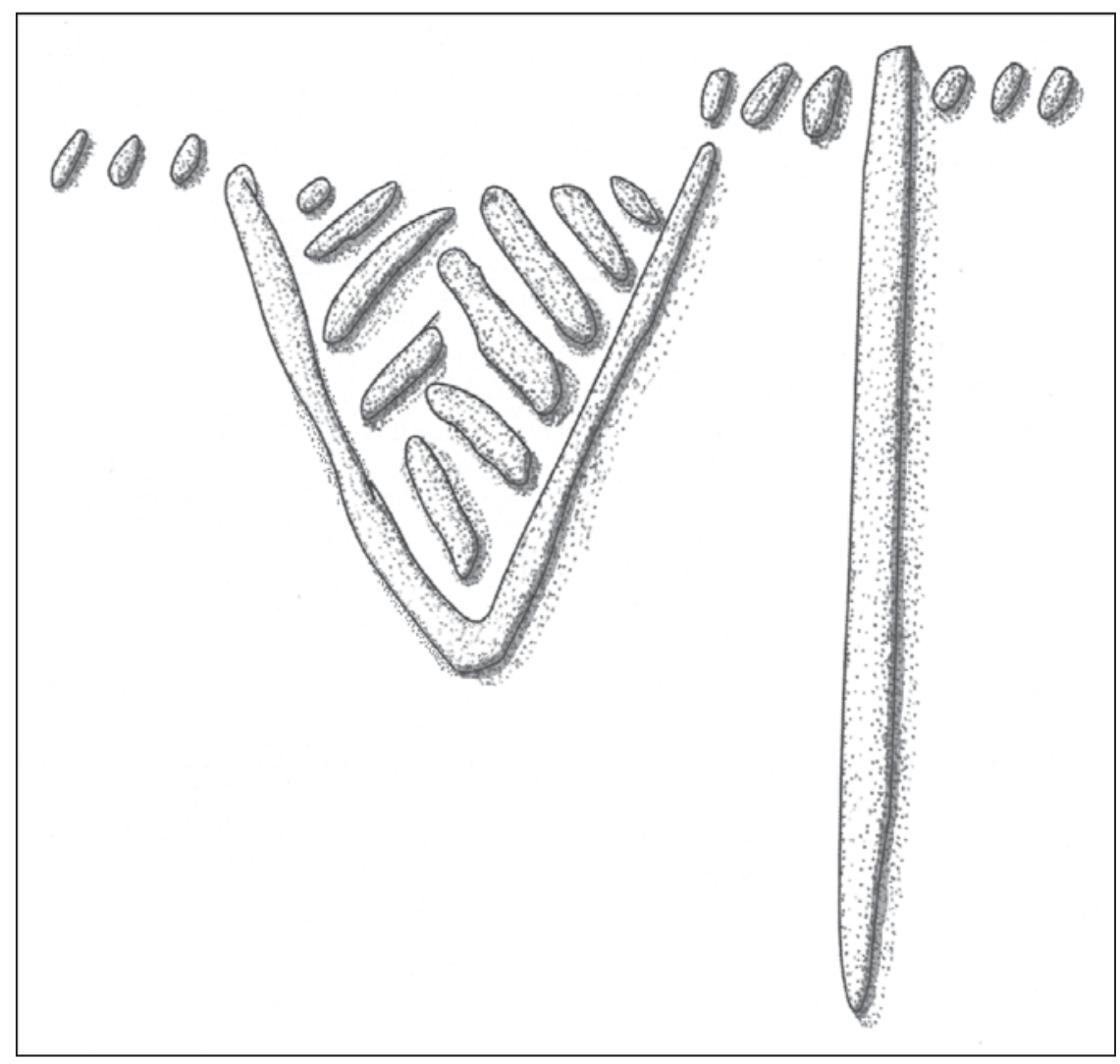

Figure 14. Decorative elements on the body of a La Rue Neck Banded jar (Burial 2, Vessel 7) from the Goldsmith site.

SITE NAME OR SITE NUMBER: Goldsmith (41WD208)

VESSEL NO.: Burial 2, Vessel 8

NON-PLASTICS AND PASTE: grog and sandy paste

VESSEL FORM: Bottle with a spool neck

RIM AND LIP FORM: Everted rim and a rounded lip

CORE COLOR: B (fired and cooled in a reducing environment)

INTERIOR SURFACE COLOR: very dark grayish-brown to black

EXTERIOR SURFACE COLOR: very dark grayish-brown to black

WALL THICKNESS (RIM, BODY, AND BASE IN MM): rim, 6.4 mm

INTERIOR SURFACE TREATMENT: none

EXTERIOR SURFACE TREATMENT: burnished 
HEIGHT (IN CM): 19.8

ORIFICE DIAMETER (IN CM): 6.0

DIAMETER AT BOTTOM OF RIM OR NECK (IN CM): 5.6; maximum body width is $14.8 \mathrm{~cm}$

BASE DIAMETER (IN CM) AND SHAPE OF BASE: N/A, circular and rounded

ESTIMATED VOLUME (IN LITERS): 0.47

DECORATION (INCLUDING MOTIF AND ELEMENTS WHEN APPARENT): The vessel body has tight engraved circular and concentric spirals that end in two arms of spirals that hook around each other and do not touch (Figure 15). These sets of spirals are repeated four times around the vessel. Below the circular spirals, and above the vessel base, are five sets of curvilinear spirals.

PIGMENT USE AND LOCATION ON VESSEL: none

TYPE AND VARIETY [IF KNOWN]: Taylor Engraved

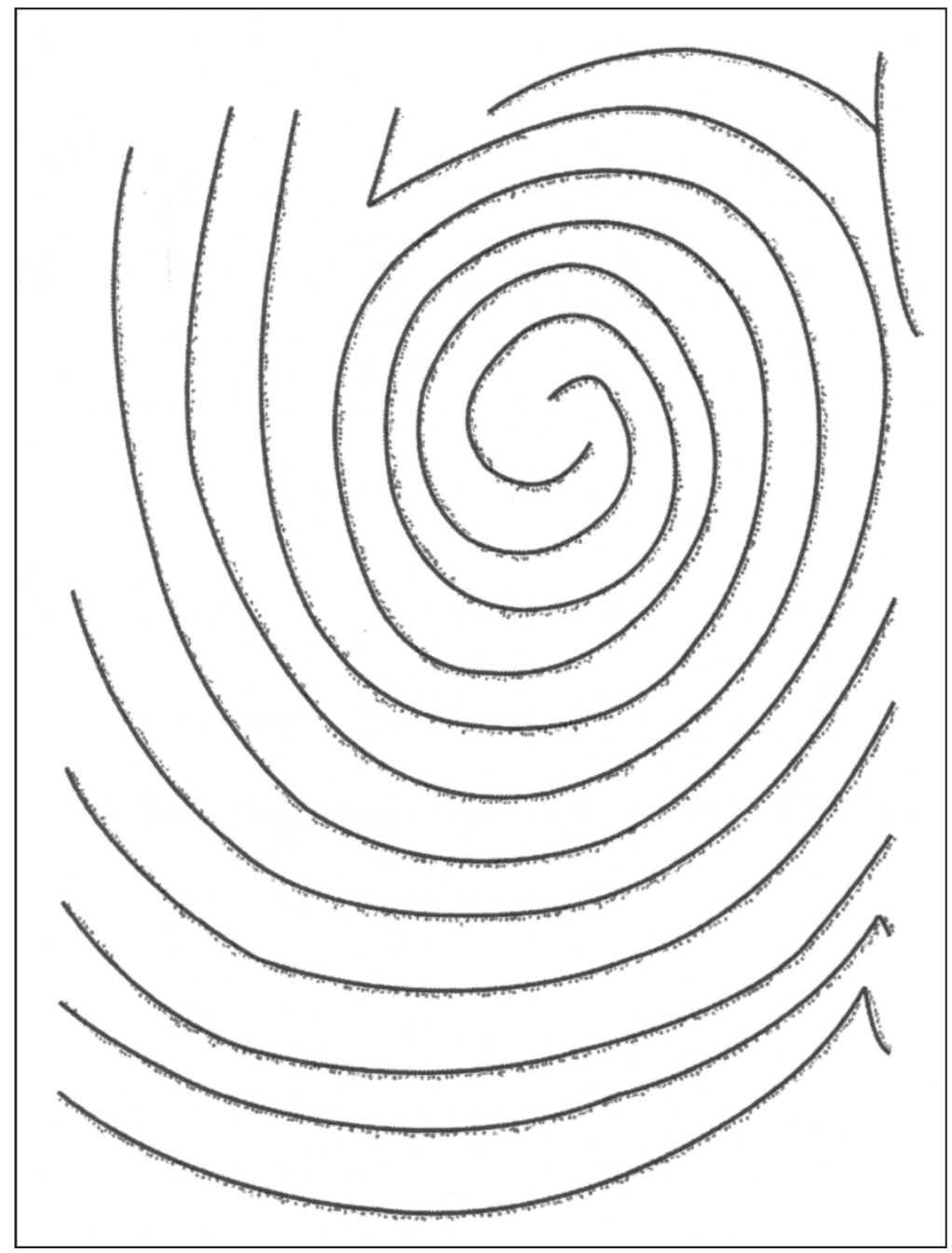

Figure 15. Decorative elements on Taylor Engraved bottle (Burial 2, Vessel 8) from the Goldsmith site. 
SITE NAME OR SITE NUMBER: Goldsmith (41WD208)

VESSEL NO.: Burial 2, Vessel 9

NON-PLASTICS AND PASTE: grog

VESSEL FORM: Jar

RIM AND LIP FORM: Everted rim and a rounded lip

CORE COLOR: $\mathrm{F}$ (fired in a reducing environment and cooled in the open air)

INTERIOR SURFACE COLOR: yellowish-brown

EXTERIOR SURFACE COLOR: dark yellowish-brown; fire clouds on the rim and body

WALL THICKNESS (RIM, BODY, AND BASE IN MM): rim, 6.4 mm; body, 7.9 mm

INTERIOR SURFACE TREATMENT: smoothed

EXTERIOR SURFACE TREATMENT: none

HEIGHT (IN CM): 18.0

ORIFICE DIAMETER (IN CM): 17.5

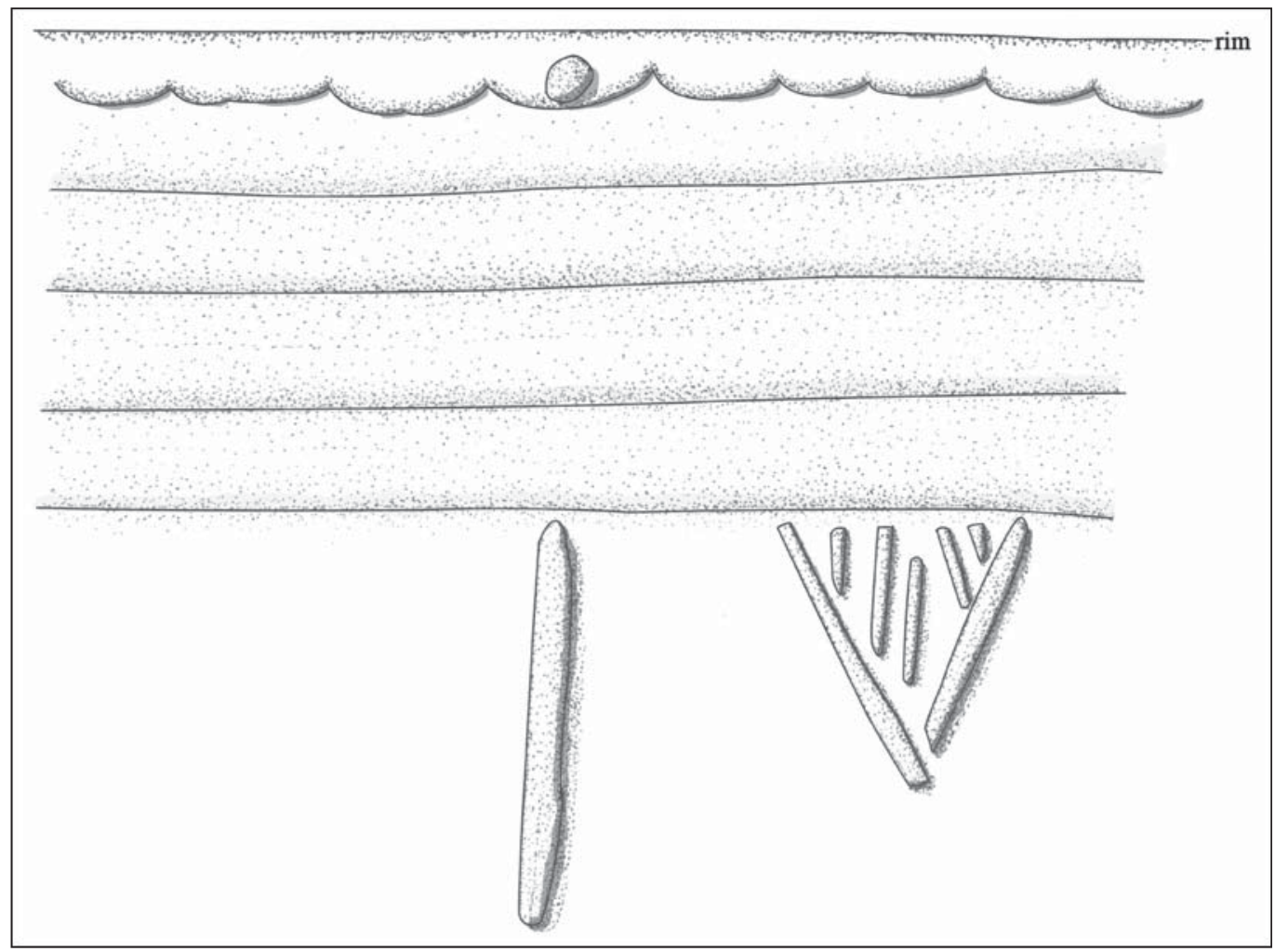

Figure 16. Decorative elements on a La Rue Neck Banded jar (Burial 2, Vessel 9) from the Goldsmith site. 
DIAMETER AT BOTTOM OF RIM OR NECK (IN CM): 15.5

BASE DIAMETER (IN CM) AND SHAPE OF BASE: 8.0; circular and flat

ESTIMATED VOLUME (IN LITERS): 2.8

DECORATION (INCLUDING MOTIF AND ELEMENTS WHEN APPARENT): The rim has a single smoothed over neck banded coil followed by four shallow horizontal grooved areas (Figure 16). There are also four equally-spaced appliqued nodes on the neck banded coil at the top of the rim. The vessel body has four vertical appliqued ridges that extend from the rim-body juncture down the vessel; these ridges are aligned with the appliqued nodes on the rim. Between these vertical appliqued ridges are four large appliqued triangles pendant from the rim-body juncture (Figure 16). These appliqued triangle elements are filled with both short vertical and diagonal appliqued ridge elements.

PIGMENT USE AND LOCATION ON VESSEL: none

TYPE AND VARIETY [IF KNOWN]: La Rue Neck Banded

\section{SUMMARY AND CONCLUSIONS}

The 18 vessels documented from the Burks (41WD52), Holly Lake Ranch (41WD57), and the Goldsmith site (41WD208) are from four different Late Caddo period Titus phase burials in cemeteries in the Lake Fork Creek basin in Wood County. The majority of the vessels are fine ware carinated bowls $(n=10,56$ percent of the sample) and bottles ( $n=3,17$ percent of the documented vessels), but decorated utility wares ( $n=5,28$ percent of the documented vessels) are also present in these vessel assemblages. The vessels are uniformly tempered with grog (one of the vessels has grog and bone temper) and they had been fired in a reducing environment; the majority of the vessels were removed from the fire and then cooled in the open air.

The principal fine wares in the carinated bowls are represented by several varieties of Ripley Engraved, including cf. var. Cash $(\mathrm{n}=1)$, cf. var. Carpenter $(\mathrm{n}=1)$, var. Williams $(\mathrm{n}=1)$, var. Pilgrims $(\mathrm{n}=1)$, var. Galt $(\mathrm{n}=4)$, and var. unspecified $(\mathrm{n}=1)$. One fine ware carinated bowl is decorated only on its interior surface by a single horizontal engraved line at the carination. Fine ware bottles include Wilder Engraved, var. Wilder $(n=2)$ and Taylor Engraved $(n=1)$. Clay pigments were commonly added to the engraved designs on these fine wares, including 80 percent of the carinated bowls and 33 percent of the bottles. A red clay (hematiterich) pigment occurs on 38 percent of the fine wares and a white clay (kaolin-rich) pigment occurs on 31 percent of the fine wares.

The utility wares in this collection are jars. They are represented by La Rue Neck Banded vessels $(n=4)$ and a single cf. Maydelle Incised vessel. None of the jars have sturdy handles, but several have small pseudolug handles as well as four rim peaks.

\section{ACKNOWLEDGMENTS}

We appreciate the drawings prepared by Lance Trask of the decorative elements and motifs on selected vessels illustrated in this article. 


\section{REFERENCES CITED}

Perttula, T. K., with the contributions of B. D. Skiles and B. C. Yates

2005 The M. W. Burks Site (41WD52), A Late Caddo Hamlet in Wood County, Texas. Journal of Northeast Texas Archaeology 23:1-27.

Perttula, T. K., P. S. Marceaux, and B. Nelson

2012 Study of the Margaret Hinton Collection of Pottery Vessels from Northeast Texas Caddo Cemeteries. Special Publication No. 24. Friends of Northeast Texas Archaeology, Austin and Pittsburg.

Perttula, T. K., B. D. Skiles, and B. C. Yates

1993 The Goldsmith Site (41WD208): Investigations of the Titus Phase in the Upper Sabine River Basin, Northeast Texas. Bulletin of the Texas Archeological Society 61:139-191.

Perttula, T. K., B. D. Skiles, M. B. Collins, M. C. Trachte, and F. Valdez, Jr.

1986 "This Everlasting Sand Bed": Cultural Resources Investigations at the Two Big Sandy Project, Wood and Upshur Counties, Texas. Reports of Investigations No. 52. Prewitt and Associates, Inc., Austin. 